\title{
TOTAL POLIFENOL DAN AKTIVITAS ANTIOKSIDAN YOGHURT DENGAN PENAMBAHAN TEPUNG JEWAWUT
}

(Total polyphenols and antioxidant activity yoghurt with addition of millet flour)

\author{
Laksito Rukmi, D., ${ }^{1}$, Legowo , A M. ${ }^{2}$, dan Dwiloka, B ${ }^{3}$ \\ 1) Mahasiswa Pasca Sarjana Fakultas Peternakan Dan Pertanian Universitas Diponegoro \\ Kampus drh. Soejono Koesoemowardojo Tembalang Semarang 50275 \\ E-mail : dyah laksito@yahoo.co.id \\ ${ }^{2,3)}$ Staf pengajar Fakultas Peternakan dan Pertanian, Universitas Diponegoro \\ Kampus drh. R. Soejono Kusumowardojo Tembalang, Semarang 50275
}

Diterima : 15 Desember 2014 Disetujui : 25 November 2015

\begin{abstract}
The purpose of this study was to determine the total polyphenols and antioxidant activity of yogurt with millet flour addition. The research design used was a completely randomized design (CRD) with 3 treatments and 7 replications. Treatments are $L$. acidophilus starter inoculation comparison with $S$. thermophilus of $1: 1(v / v)$, consisting of $T 1=3 \% ; T 2=4 \% ; T 3=5 \%$. Based on the results of comparative studies starter inoculum affect significantly $(P<0.05)$ of total polyphenols and antioxidant activity. Total polyphenols increase from $50.30 \mathrm{ppm}$ to $69.44 \mathrm{ppm}$ and antioxidant activity increase from $9.55 \%$ to 11.41 $\%$.
\end{abstract}

Keywords: yoghurt, millet flour, starter inoculation

\begin{abstract}
ABSTRAK
Tujuan dari penelitian ini adalah untuk mengetahui total polifenol dan aktivitas antioksidan yoghurt dengan penambahan tepung jewawut. Rancangan penelitian yang digunakan adalah rancangan acak lengkap (RAL) dengan tiga perlakuan dan tujuh ulangan. Perlakuan yang diberikan adalah perbandingan inokulasi starter $L$. acidophilus dengan $S$. thermophilus sebesar 1: $1(\mathrm{v} / \mathrm{v})$, terdiri atas $\mathrm{T} 1=3 \% ; \mathrm{T} 2=4 \% ; \mathrm{T} 3=5 \%$. Berdasarkan hasil penelitian perbandingan inokulasi starter berpengaruh secara nyata $(\mathrm{P}<0,05)$ terhadap total polifenol dan aktivitas antioksidan. Total polifenol meningkat dari 50,30 ppm sampai 69,44 ppm dan aktivitas antioksidan meningkat dari 9,55\% sampai $11,41 \%$
\end{abstract}

Kata kunci: yoghurt, tepung jewawut, inokulasi starter

\section{PENDAHULUAN}

Yoghurt adalah produk susu fermentasi bergizi tinggi namun tidak mengandung serat. Dalam beberapa tahun terakhir, penambahan serat makanan dalam produk susu fermentasi telah meningkatkan keragaman di bidang pangan fungsional. Sebagian besar aplikasi serat pangan untuk yoghurt terkait dengan penggunaan serat pangan yang larut dalam air karena mempunyai sifat mengikat air. Serat pangan yang ditambahkan dalam proses pengolahan 
yoghurt pada penelitian ini adalah tepung jewawut.

Millet/jewawut (Setaria italica L.) termasuk tanaman tahan kering, sesuai di lahan marginal mampu berproduksi 3-4 t/ha. Menurut (Nurmala 2003) produksinya jewawut di Indonesia mampu mencapai 4,0 t/ha di lahan marginal sementara tanaman pangan lain kurang berhasil. Jewawut dapat dijadikan sebagai sumber energi, protein, kalsium, vitamin B-1, riboflavin (B-2), sedangkan nutrisi lainnya setara dengan beras. Jewawut juga mengandung senyawa penting seperti vitamin $\mathrm{B}$, antioksidan bioaktif dan serat. Selain itu jewawut mengandung gluten yang sifatnya elastis, kedap udara, sehingga tidak mudah putus saat pencetakan mie

Komponen serat pangan yang terkandung dalam jewawut menurut Muchtadi et al. (1992) yaitu hemiselulosa, selulosa, ester - ester fenolik, dan glikoprotein. Sedangkan komponen lainnya seperti glukan, pektin, dan mucilage merupakan serat pangan mudah larut (soluble dietary fiber) yang mudah terfermentasi oleh mikroba. Menurut Suhartono (2002), ester - ester fenolik pada jewawut dapat membentuk polifenol yang berfungsi sebagai antioksidan. Antioksidan merupakan zat yang mampu memperlambat atau mencegah proses oksidasi. Antioksidan adalah senyawa kimia yang dapat menyumbangkan satu atau lebih elektron kepada radikal bebas, sehingga radikal bebas tersebut dapat diredam.

Tubuh manusia tidak mempunyai cadangan antioksidan dalam jumlah berlebih, sehingga jika terjadi paparan radikal berlebih maka tubuh membutuhkan antioksidan eksogen. Adanya kekhawatiran akan kemungkinan efek samping yang belum diketahui dari antioksidan sintetik menyebabkan antioksidan alami menjadi alternatif yang sangat dibutuhkan (Schmidl et al, 2000) Oleh karena itu, berdasarkan latar belakang tersebut dilakukan penelitian mengenai tepung jewawut menjadi sumber serat pangan yang ditambahkan pada yoghurt dengan tujuan untuk memanfaatkan probiotik dalam yoghurt untuk memaksimalkan kesehatan saluran pencernaan manusia serta sebagai antioksidan alami yang aman dan bermanfaat bagi kesehatan bagi tubuh manusia.

\section{MATERI DAN METODE}

Penelitian ini dilaksanakan pada bulan Juli 2014 di Laboratorium Ilmu Nutrisi Pakan dan Laboratorium Ekologi dan Produksi Tanaman, Fakultas Peternakan dan Pertanian, Universitas Diponegoro, Semarang.

\section{Materi Penelitian}

Bahan yang digunakan dalam pembuatan yoghurt adalah susu sapi, kultur starter (Lactobacillus acidophilus FNCC 0051 dan Streptococcus thermophilus FNCC 0040 yang diperoleh dari Pusat Studi Pangan dan Gizi Universitas Gadjah Mada Yogyakarta) dan jewawut (Setaria italica) yang diperoleh dari Pasar Kartini. Bahan yang digunakan dalam uji total bakteri asam laktat antara lain aquades, medium $M R S$ Broth. Reagen yang dibutuhkan untuk pengujian total polifenol yaitu : reagen Folin Ciocalteu, larutan induk asam galat, $\mathrm{Na}_{2} \mathrm{CO}_{3}$ $20 \%$, dan aquabides. Pengujian aktivitas antioksidan membutuhkan larutan DPPH atau 2,2-dypheny-1-picrylhydrazil dan etanol. Alat - alat yang dibutuhkan dalam penelitian ini meliputi : mikro pipet, kuvet, forteks, tabung reaksi, timbangan analitik, penangas air, inkubator, erlenmeyer, spektrofotometer, dan $\mathrm{pH}$-meter. 


\section{Metode}

\section{Persiapan Penelitian}

Persiapan penelitian dilakukan melalui beberapa kegiatan yaitu penghitungan alat dan bahan, sterilisasi alat, media, dan sterilisasi ruangan. Alat yang tahan panas disterilisasi kering dalam oven dengan suhu $170{ }^{\circ} \mathrm{C}$ selama 1 jam. Sedangkan media yang digunakan untuk menumbuhkan bakteri (MRS broth) disterilisasi dengan autoklaf pada suhu $121{ }^{\circ} \mathrm{C}$ selama 15 menit. Ruangan dan meja yang akan digunakan dibuat aseptis dengan penyemprotan alkohol $70 \%$.

\section{Penelitian Pendahuluan}

Kegiatan yang terangkum dalam penelitian pendahuluan yaitu: pengolahan biji jewawut menjadi tepung jewawut. Proses pembuatan tepung jewawut dimulai dengan memisahkan biji - bijian jewawut dari kotoran yang ada dengan cara ditampi, untuk mendapatkan bijian jewawut yang bersih. Selanjutnya merendam jewawut dalam air, mengeringkannya, memblender hingga halus, diayak lalu melakukan sterilisasi dengan autoklaf pada suhu $121^{\circ} \mathrm{C}$ selama 15 menit.

\section{Penelitian Utama}

Penelitian tahap kedua bertujuan untuk menganalisis pengaruh jumlah starter terhadap kualitas yoghurt jewawut. Peneltian tahap kedua dimulai dari menumbuhkan starter BAL dalam media MRS broth (Ilustrasi 1), pembuatan Mother Starter dalam media susu (Ilustrasi 2), dan pembuatan yoghurt jewawut (Ilustrasi 3).

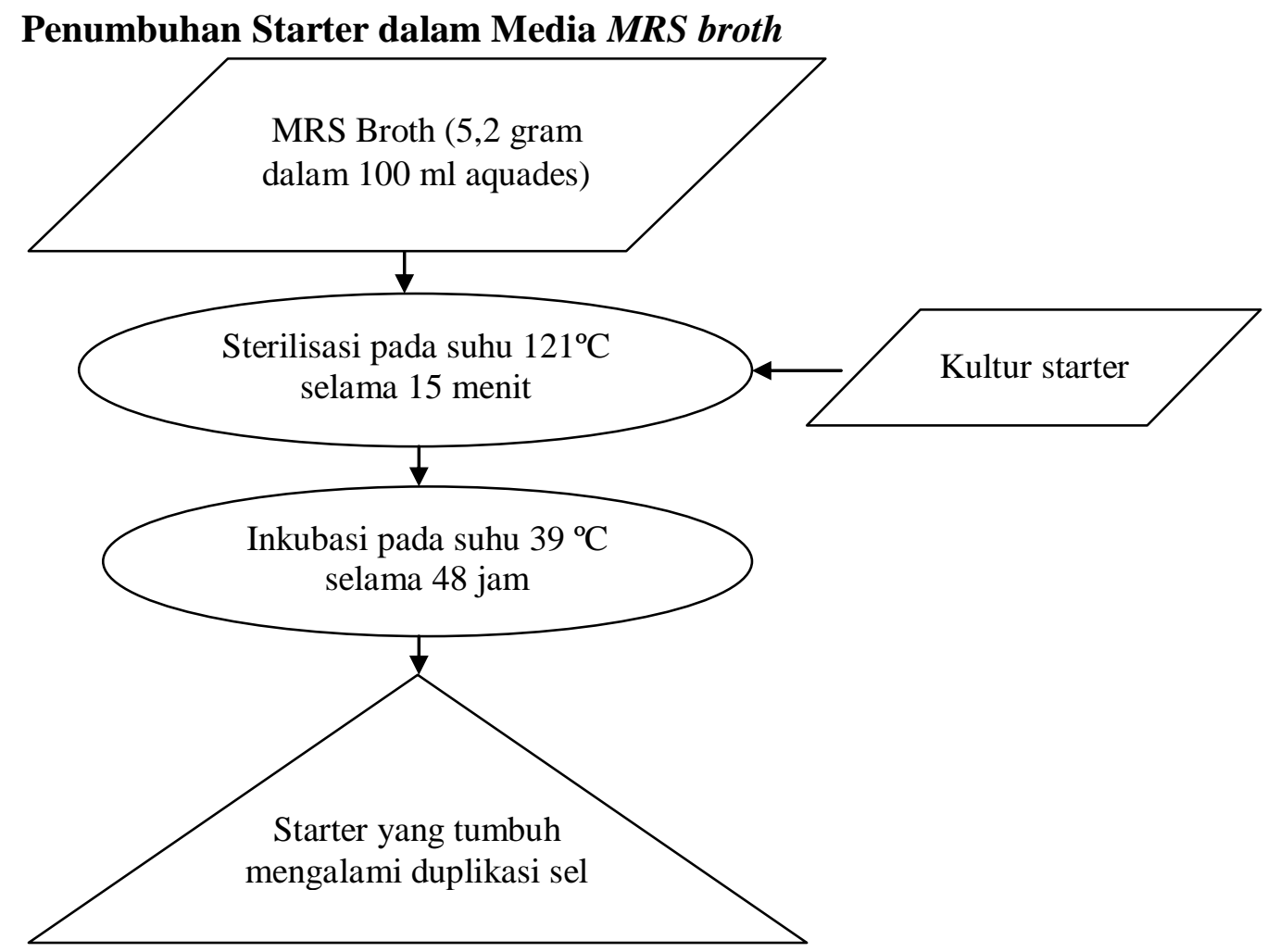

Ilustrasi 1. Diagram Alir Penumbuhan Starter dalam Media MRS broth (Widowati dan Misgiyarta, 2007) 


\section{Penumbuhan Starter dalam Media Susu}

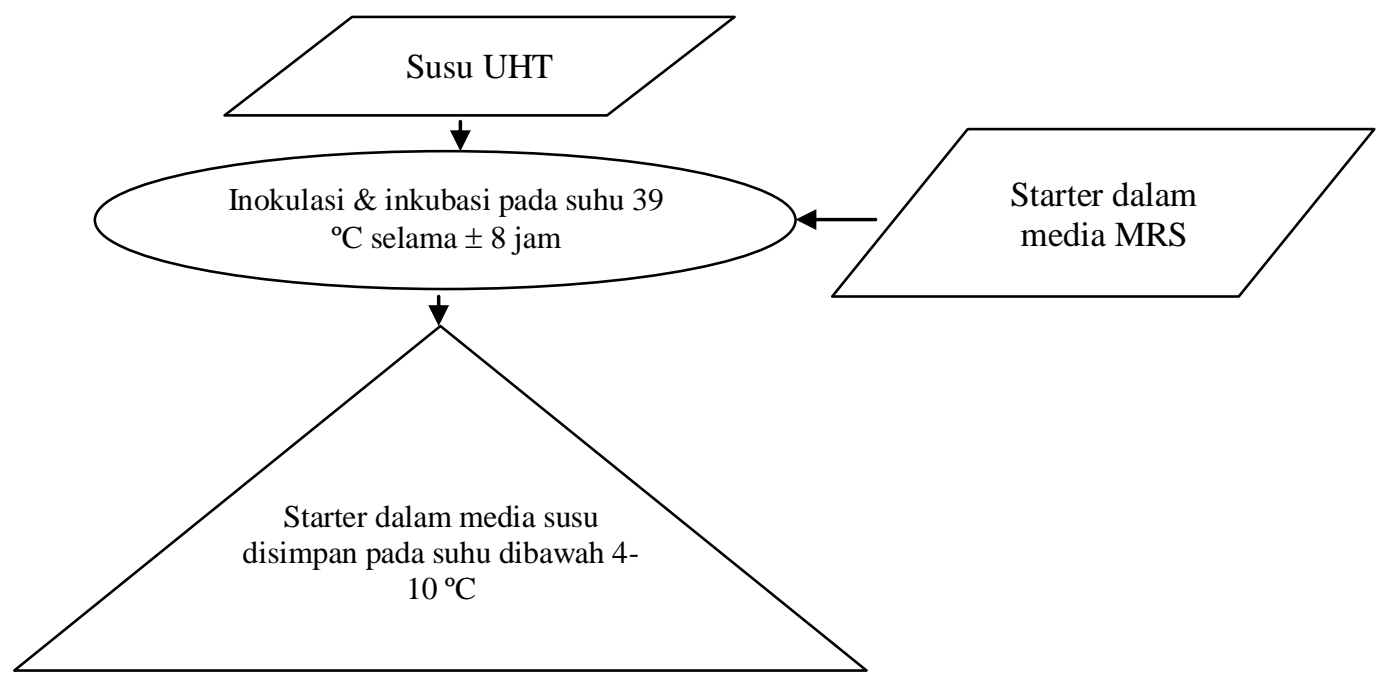

Ilustrasi 2. Diagram Alir Penumbuhan Starter dalam Media Susu (Widowati dan Misgiyarta, 2007, dengan modifikasi)

\section{Proses Pembuatan Yoghurt}

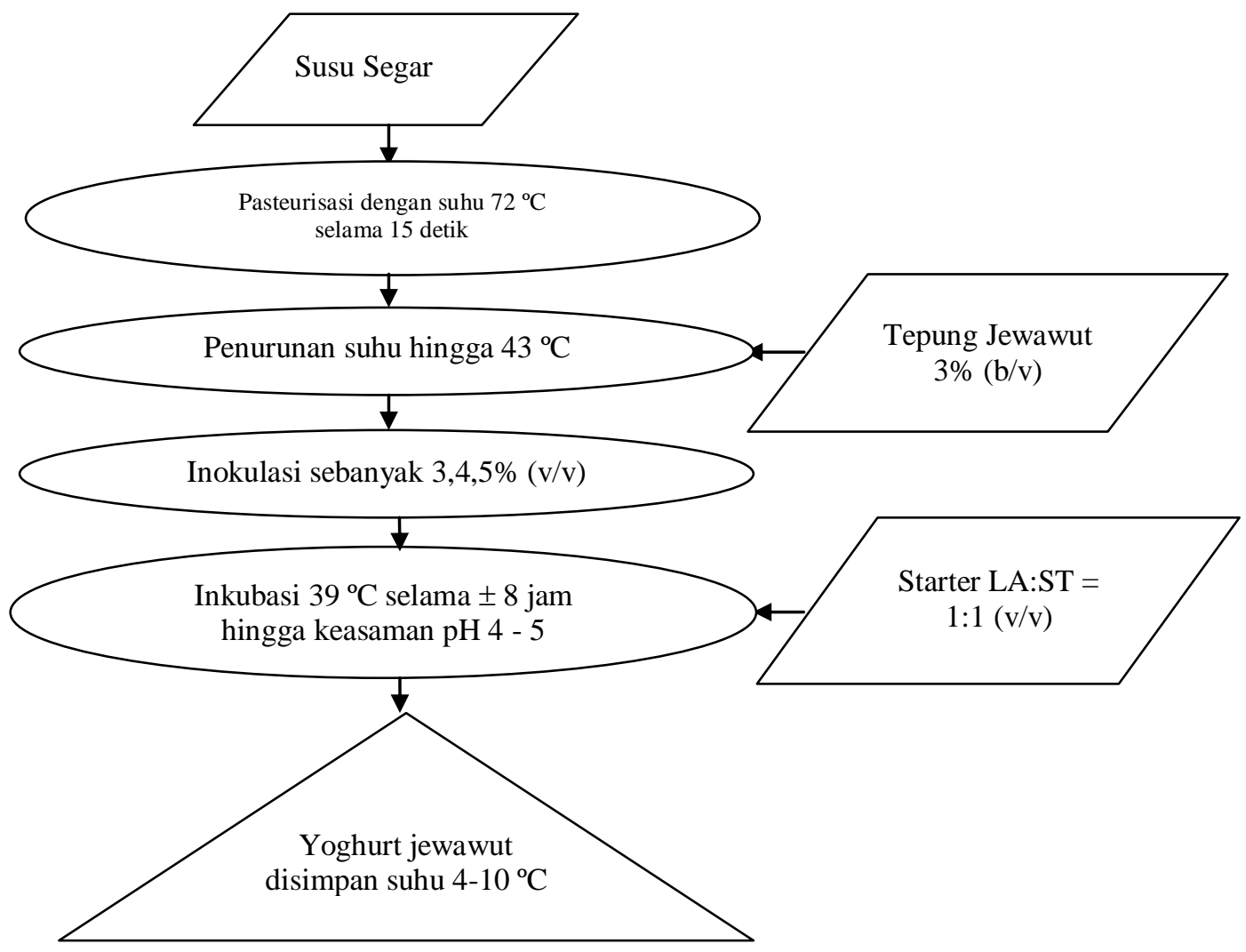

Ilustrasi 3. Diagram Alir Proses Pengolahan Yoghurt dengan Penambahan Tepung Jewawut (Legowo, 2005, dengan modifikasi) 


\section{Perlakuan}

Perlakuan yang diberikan adalah variasi jumlah starter dengan persentase yang berbeda. Perlakuan yang diberikan pada proses pembuatan yoghurt jewawut antara lain :

$\mathrm{T}_{1}=$ Perbandingan inokulasi starter $L$. acidophilus dengan $S$. thermophilus sebesar 1 : 1 sebanyak $3 \%$ dari volume susu (v/v).

$\mathrm{T}_{2}=$ Perbandingan inokulasi starter $L$. acidophilus dengan $S$. thermophilus sebesar 1 : 1 sebanyak $4 \%$ dari volume susu (v/v).

$\mathrm{T}_{3}=$ Perbandingan inokulasi starter $L$. acidophilus dengan $S$. thermophilus sebesar 1 : 1 sebanyak 5\% dari volume susu (v/v).

\section{Parameter dan Prosedur Pengujian}

1) Total Polifenol (Waterhouse, 1999)

Pengujian total polifenol diawali dengan pembuatan larutan $\mathrm{Na}_{2} \mathrm{CO}_{3} 20 \%$ dan larutan induk asam galat. Pembuatan larutan $\mathrm{Na}_{2} \mathrm{CO}_{3} 20 \%$ yaitu menimbang $5 \mathrm{~g} \quad \mathrm{Na}_{2} \mathrm{CO}_{3}$ dan tambahkan $20 \mathrm{ml}$ aquabidest lalu didihkan kemudian diamkan selam 24 jam, saring dan encerkan dengan aquabidest $25 \mathrm{ml}$. Pembuatan larutan induk asam galat $(5 \mathrm{mg} / \mathrm{ml})$ yaitu menimbang $0,25 \mathrm{~g}$ asam galat tambahkan $5 \mathrm{ml}$ etanol $96 \%$ dan tambahkan aquabidest sampai $50 \mathrm{ml}$, sehingga diperoleh konsentrasi 5 $\mathrm{mg} / \mathrm{ml}$. Dari larutan induk dipipet 6, 8 , 10, 12, $14 \mathrm{ml}$ dan diencerkan dengan aquabidest sampai volumenya $100 \mathrm{ml}$, sehingga dihasilkan dengan konsentrasi 300, 400, 500, 600, dan $700 \mathrm{mg} / \mathrm{L}$ asam galat. Dari masingmasing konsentrasi di atas dipipet 0,2 $\mathrm{ml}$ tambah 15, $8 \mathrm{ml}$ aquabidest ditambah $1 \mathrm{ml}$ Reagen Folin Ciocalteu kocok. Diamkan selama 8 menit tambah $3 \mathrm{ml}$ larutan $\mathrm{Na}_{2} \mathrm{CO}_{3} \quad 20 \%$ kocok homogen. Diamkan selama 2 jam pada suhu kamar. Ukur serapan pada panjang gelombang serapan maksimum $765 \mathrm{~nm}$, lalu buat kurva kaliberasi hubungan antara konsentrasi asam galat $(\mathrm{mg} / \mathrm{L})$ dengan absorban.

\section{2) Aktivitas Antioksidan (Yen dan Cheng, 1995).}

Menimbang 1-2 g sampel kemudian larutkan menggunakan methanol pada konsentrasi tertentu. Ambil $1 \mathrm{ml}$ larutan induk ,masukkan pada tabung reaksi. Tambahkan $1 \mathrm{ml}$ larutan $1,1,2$ ,2 -Diphenyl Picryl Hydrazyl (DPPH) $200 \mu \mathrm{M}$. Inkubasikan pada ruang gelap selama 30 menit. Encerkan hingga $5 \mathrm{ml}$ menggunakan etanol. Buat blanko (1ml larutan DPPH $+4 \mathrm{ml}$ etanol). Tera pada panjang gelombang $515 \mathrm{~nm}$ Total Antioksidan ( \% )

$$
=\frac{\text { OD Blangko }- \text { OD Sampel }}{\text { OD Blangko }} \times 100 \% \text {.....(1) }
$$

\section{Analisis Data}

Design penelitian yang digunakan dalam penelitian ini adalah Rancangan Acak Lengkap dengan tiga perlakuan dan tujuh ulangan (Gomez dan Gomez, 1995). Data yang diperoleh dari hasil pengujian dianalisis menggunakan analisis ragam pada taraf signifikansi 5\%,jika terdapat pengaruh nyata, maka diuji lanjut dengan uji Wilayah Ganda Duncan untuk mengetahui perbendaan antar perlakuan. Data ini dihitung dengan bantuan program SAS 9.13 


\section{HASIL DAN PEMBAHASAN}

\section{Kandungan Nutrien Tepung Jewawut}

Jewawut yang dipakai dalam penelitian ini memiliki kandungan nutrien sebagai berikut: 13,57\% air; 3,61 protein kasar; 1,7\% lemak kasar; 2,22\% serat kasar; 2.3\% abu; dan $78,83 \%$ karbohidrat. Sedangkan kandungan serat pangan tak larut air sebesar $10,44 \%$ dan serat pangan larut airnya sebesar $0,31 \%$. Kandungan serat kasar jewawut yang digunakan dalam penelitian ini cukup tinggi, yaitu sekitar 2,22\%. Kandungan jewawut menurut Widyaningsih dan Mutholib (1999) meliputi 84,2\% karbohidrat; $10,7 \%$ protein; $3,3 \%$ lemak; dan $1,4 \%$ serat. Dijelaskan lebih lanjut untuk kandungan mineral $\mathrm{Ca}$, Fe, Vit $\mathrm{B}_{1}$, Vit $\mathrm{B}_{2}$, dan Vit $\mathrm{C}$ tiap 100 gram jewawut berturut-turut yaitu sebesar 37; 6,2; 0,48; 0,14; dan 2,5 gram/mg. Tingginya kadar serat kasar pada jewawut tersebut menjadi latar belakang penambahan jewawut ke dalam yoghurt sebagai sumber serat.

\section{Pengaruh Inokulasi Kultur Starter terhadap Total Polifenol Yoghurt dengan Penambahan Tepung Jewawut}

Total polifenol semakin meningkat dengan semakin banyaknya penambahan jumlah starter. Selama fermentasi, terjadi peningkatan total polifenol pada yoghurt jewawut. Hal ini sejalan dengan analisis serat pangan, semakin tinggi penurunan kadar serat pangan jewawut pada yoghurt semakin tinggi pula senyawa fenolik yang terdeteksi. Data hasil pengujian total polifenol yoghurt dengan penambahan tepung jewawut disajikan pada Tabel 1.

Jewawut mengandung komponen fitokimia seperti komponen fenolik yang terdiri atas fenol, dan golongan flavonoid. Glukan merupakan salah satu komponen yang penting dalam sorgum dan jewawut, dimana senyawa ini berfungsi sebagai imunomodulator, antiateroskerosis, antiradiasi dan antioksidan (Schmidl dan Labuza, 2000). Komponen asam fenolik yang tinggi adalah jenis asam ferulat, kaumarat, sianamat, dan gensitin. Komponen fenolik ini memiliki sifat antioksidan yang dapat menekan reaksi oksidasi yang merugikan bagi tubuh.

Tabel 1. Pengaruh Inokulasi Kultur Starter terhadap Total Polifenol Yoghurt dengan Penambahan Tepung Jewawut

\begin{tabular}{|c|c|c|c|}
\hline \multirow[t]{2}{*}{ Ulangan } & \multicolumn{3}{|c|}{ Total Polifenol } \\
\hline & T1 & $\mathrm{T} 2$ & T3 \\
\hline & & m) ----- & -- \\
\hline $\mathrm{u} 1$ & 51,63 & 63,16 & 66,07 \\
\hline $\mathrm{u} 2$ & 51,15 & 63,04 & 64,87 \\
\hline u3 & 51,26 & 63,16 & 73,72 \\
\hline $\mathrm{u} 4$ & 51,63 & 54,80 & 83,92 \\
\hline u5 & 50,78 & 55,15 & 65,00 \\
\hline u6 & 47,63 & 58,06 & 65,35 \\
\hline u7 & 44,95 & 58,92 & 67,18 \\
\hline Rerata & $50,30^{\mathrm{a}}$ & $59,47^{b}$ & $69,44^{\circ}$ \\
\hline
\end{tabular}

Keterangan : $\quad$ Superskrip yang berbeda pada kolom rerata menunjukkan perbedaan yang nyata $(\mathrm{P}<0,05)$ 
Hasil penelitian menunjukkan bahwa yoghurt dengan penambahan tepung jewawut memiliki total polifenol yang cukup tinggi yaitu sekitar 50-73 ppm atau setara dengan 0,05-0,07 $\mathrm{mg} / \mathrm{ml}$. Berdasarkan hasil penelitian Supriyono (2008) susu sapi yang difermentasi dengan Candida kefir dan $L$. bulgaricus dengan penambahan serat berupa kacang hijau mengandung total polifenol sebesar $0,0384-0,054 \mathrm{mg} / \mathrm{ml}$ atau setara dengan 38,4-54 ppm. Tingginya kandungan polifenol pada produk yoghurt dengan penambahan tepung jewawut ini diduga karena jewawut memiliki senyawa asam hidroksi sinamat maupun asam ferulat yang didekarboksilasi menjadi senyawa fenol oleh enzim dari BAL.

Kenaikan total polifenol akibat fermentasi diduga adanya senyawa fenolik yang dibebaskan selama proses fermentasi. Menurut Gawel (2004) peningkatan jumlah senyawa fenol selama fermentasi diduga karena Lactobacillus memiliki enzim ferulic acid reductase dan vinyl phenol reductase untuk mendegradasi asam ferulat dan asam sinamat yang merupakan komponen polisakarida dinding sel menjadi 4-vinyl phenol dan 4-vinyl guaiacol.

Asam yang terbentuk dihasilkan oleh Lactobacillus acidophillus yaitu dengan mengkonversi glukosa menjadi asam laktat. Reaksi oksidasi dari proses fermentasi juga menyebabkan polifenol beraksi sebagai antioksidan untuk melawan reaksi oksidasi tersebut. Hal ini sesuai dengan pendapat Kruszewka et al., 2002) yang menyatakan bahwa selain dari asam laktat, antioksidan merupakan metabolit sekunder dari metabolisme BAL. Beberapa penelitian menunjukkan bahwa bakteri probiotik meningkatkan senyawa antioksidan dalam bentuk vitamin $\mathrm{C}$ dan vitamin $\mathrm{E}$.

\section{Pengaruh Inokulasi Kultur Starter terhadap Aktivitas Antioksidan Yoghurt dengan Penambahan Jewawut}

Meningkatnya antioksidan pada yoghurt dengan penambahan tepung jewawut sejalan dengan meningkatnya total polifenol. Jewawut memiliki komponen bioaktif seperti asam fenolik, flavonoid, dan kondensat tanin yang memiliki fungsi sebagai penangkal atau memperlambat reaksi radikal bebas atau bersifat antioksidan (Awika dan Rooney, 2004). Menurut Singh et al., (2002) komponen asam ferulat, cafeat, $\rho$-caumarin, sinapat, dan flavonoid pada sorgum dan jewawut, memiliki reaktivitas yang tinggi untuk memicu terekspresinya enzim SOD, sehingga dengan pemberian konsumsi 25 $\mathrm{g} / \mathrm{Kg} \mathrm{BB}$ sudah meningkatkan kadar SOD hati secara signifikan. Menurut penelitian Sirappa (2003) bahwa asam ferulat mampunyai kemampuan antioksidan secara invitro, dengan menangkal radikal superoksida, sehingga mampu menurunkan beban oksidasi pada saluran darah, selama proses pengangkutan. Data hasil pengujian aktivitas antioksidan yoghurt disajikan pada Tabel 2. 
Tabel 2. Pengaruh Inokulasi Kultur Starter terhadap Aktivitas Antioksidan Yoghurt dengan Penambahan Tepung Jewawut

\begin{tabular}{cccc}
\hline \hline Ulangan & \multicolumn{3}{c}{ Aktivitas Antioksidan } \\
\cline { 2 - 4 } & T1 & T2 & T3 \\
u1 & 9,69 & 10,31 & 11,25 \\
u2 & 9,38 & 10,62 & 11,56 \\
u3 & 8,97 & 10,46 & 11,41 \\
u4 & 9,53 & 10,54 & 11,38 \\
u5 & 9,84 & 10,54 & 11,54 \\
u6 & 9,50 & 10,32 & 11,50 \\
u7 & 9,94 & 10,49 & 11,21 \\
\hline Rerata & $9,55^{\text {a }}$ & $10,47^{\mathrm{b}}$ & $11,41^{\mathrm{c}}$ \\
\hline
\end{tabular}

Keterangan: Superskrip yang berbeda pada kolom rerata menunjukkan perbedaan yang nyata $(\mathrm{P}<0,05)$

Semakin tinggi inokulasi starter yang diberikan, semakin tinggi total polifenol yang dilepaskan, semakin tinggi pula aktivitas antioksidannya. Hal ini diduga disebabkan adanya senyawa fenol yang terbebaskan akibat hidrolisis serat oleh BAL selama fermentasi sehingga aktivitas antioksidan fenolik meningkat. Hal ini sesuai dengan pendapat Baublis, et al. (2000) yang menyatakan bahwa senyawa fenolik memiliki aktivitas antioksidan lebih tinggi setelah dihidrolisis oleh enzim mikroba dari polisakarida yang mengikatnya. Senyawa fenolik serealia sebesar $74 \mu \mathrm{g}(0,2 \%$ dari fenolik terekstrak) memiliki aktivitas antioksidan dengan menghambat oksidasi lemak hingga 90\%. Menurut Singh et al (2002) antioksidan fenolik sulit untuk di ekstrak karena terikat pada serat tidak larut. Ikatan kovalen pada serat tidak larut dapat dihidrolisis oleh mikroba. Menurut Kruszewka (2002) terlepasnya ikatan kovalen pada serat tidak larut menyebabkan bioavaibilitas antioksidan fenolik meningkat.

\section{KESIMPULAN DAN SARAN}

\section{Kesimpulan}

Penambahan tepung jewawut ke dalam proses pengolahan yoghurt berpengaruh terhadap total polifenol dan aktivitas antioksidan. Semakin tinggi persentase penambahan starter menyebabkan semakin meningkatnya total polifenol dan aktivitas antioksidan.

\section{Saran}

Perlu penelitian lebih lanjut pada penambahan tepung jewawut untuk meningkatkan total polifenol dan aktivitas antioksidan

\section{DAFTAR PUSTAKA}

Awika, J.M. dan Rooney L.W. 2004. Sorghum phytochemical and their potential impact on human health. $J$. Sci Direct: Phytochemistry 65:11991221.

Baublis, A., E.A. Decker, F.M. Clydesdale. 2000. Antioxidant effect of aqueous extracts from wheat based ready to 
eat breakfast cereals. J. Food Chem 68: $1-6$.

Gawel, R. 2004. Brettanomyces Character in Wine. The Australian Society of Wine Education National Convention. Hunter Valley, Australia. $4^{\text {th }}-6^{\text {th }}$ of June 2004.

Gomez, K. A dan A.A Gomez. 1995. Prosedur Statistik untuk Penelitian Pertanian Edisi kedua. Badan Penerbit Universitas Indonesia, Jakarta.

Legowo, A. M. 2005. Diktat Kuliah Teknologi Pengolahan Susu. Universitas Diponegoro, Semarang (Tidak Diterbitkan)

Muchtadi, D., N. S. Palupi, dan M. Astawan. 1993. Petunjuk Laboratorium : Metoda Kimia Biokimia dan Biologi dalam Evaluasi Nilai Gizi Pangan Olahan. Pusat antar Universitas Pangan dan Gizi. Institut Pertanian Bogor, Bogor.

Kruszewka, H, T. Zareba, and S. Tvski. 2002. Search of antimicrobial activity of selected non-antibiotic drugs. Acta Pol Pharm 59 (6):436-439.

Nurmala, T. 2003. Prospek Jewawut (Pinnisetum spp.) Sebagai Pangan Serealia Alternatif. Jurnal Bionatura 5 (1):11-20.

Schmidl, M.K. dan T.P. Labuza 2000. Essentials of Functional Foods. USA: Aspen Publisher Inc. Maryland.

Singh, R.P., Murthy K.N.C., Jayaprakasha G.K. 2002. Studies on antioxidant activity of ponegranate (Punica granatum) peel and seed extract using in vitro model. J.Agri Food Chem 50:81-86.
Sirappa, S.A. 2003. Pholyfenol : antioxidant and beyond. J.Clinical Nutrition 81(1):215-229.

Suhartono, E., Fujiati, and I. Aflanie. 2002. Oxygen toxicity by radiation and effect of glutamic piruvat transamine (GPT) activity rat plasma after vitamine $\mathrm{C}$ treatmen, Diajukan pada International seminar on Environmental Chemistry and Toxicology, Yogyakarta.

Supriyono, T. 2008. Kandungan Beta Karoten, Polifenol Total, dan Aktivitas "Merantas" Radikal Bebas Kefir Susu Kacang Hijau (Vigna radiata) Oleh Pengaruh (Lactobacillus bulgaricus dan Candida kefir) dan Konsentrasi Glukosa. Tesis. Universitas Diponegoro, Semarang .

Widowati, S dan Misgiyarta. 2007. Efektifitas Bakteri Asam Laktat (BAL) dalam Pembuatan Produk Fermentasi Berbasis Protein/Susu Nabati. Balai Penelitian Bioteknologi dan Sumberdaya Genetik Pertanian Prosiding Seminar Hasil Penelitian Rintisan dan Bioteknologi Tanaman, Jakarta, 360 - 373.

Widyaningsih, S. dan A. Mutholib. 1999. Pakan Burung. Penebar Swadaya, Jakarta 